\title{
PARTISIPASI POLITIK PEMILIH PEMULA DALAM PESTA DEMOKRASI
}

\author{
Azirah \\ azirahzira.az@gmail.com
}

IAIN Langsa

\begin{abstract}
Beginner voters have different characteristics with older people in general. Beginner voters tend to be critical, self-contained, independent and are not satisfied with the establishment, pro-change and so on. The characteristics condusive to building a community of intelligent voters in the general election voters have rational consideration in determining his choice. For example, because the integrity of the political party leaders nominated, track record or work programs are offered. Because it has not had experience in presidential elections, beginner voters need to know and understand the various matters related to the election is held, what are the stages of the election, anyone who is eligible to participate in the elections, how the procedures for exercising the right to vote in elections and so on. The beginner voters expexted that still can maintain their political participation, so that when the quota rights of beginner voters can be run by continuing to participate at this stage then democracy will be able to bring the era of Indonesian democracy at this stage of the better later on, of course it would be better anyway when beginner voters can choose intelligently based sciences that have been obtained and supported with good ethics is also based on conscience and integrity in the absence of negative things from those who play with a sense of cheating.
\end{abstract}

Keywords: political participation, beginner voters, general election.

\begin{abstract}
ABSTRAK
Pemilih pemula memiliki karakteristik yang berbeda dengan orang-orang tua pada umumnya. Pemilih pemula cenderung kritis, mandiri, independen serta tidak puas dengan kemapanan, pro perubahan dan sebagainya. Karakteristrik itu cukup kondusif untuk membangun komunitas pemilih cerdas dalam pemilu yakni pemilih yang memiliki pertimbangan rasional dalam menentukan pilihannya. Misalnya karena integritas tokoh yang dicalonkan partai politik, track record
\end{abstract}


atau program kerja yang ditawarkan. Karena belum punya pengalaman memilih dalam pemilu, pemilih pemula perlu mengetahui dan memahami berbagai hal yang terkait dengan pemilu. Misalnya untuk apa pemilu diselenggarakan, apa saja tahapan pemilu, siapa saja yang boleh ikut serta dalam pemilu, bagaimana tata cara menggunakan hak pilih dalam pemilu dan sebagainya. Pemilih pemula diharapkan tetap dapat mempertahankan partisipasi politiknya, sehingga ketika kuota hak pemilih pemula ini dapat dijalankan dengan terus berpartisipasi pada pentas demokrasi maka ini akan dapat membawa era demokrasi Indonesia pada tahap yang lebih baik nantinya, tentunya hal itu akan lebih baik pula ketika pemilih pemula dapat memilih dengan cerdas berdasarkan ilmu-ilmu yang telah didapatkan serta didukung dengan etika yang baik pula berdasarkan hati nurani dan integritas tanpa adanya hal-hal negatif dari pihak-pihak yang bermain dengan rasa kecurangan.

Kata kunci : Partisipasi politik, pemilih pemula, pemilihan umum

\section{PENDAHULUAN}

Pesta demokrasi atau yang lebih kita kenal dengan Pemilihan Umum (pemilu) adalah memilih seorang penguasa, pejabat atau lainnya dengan jalan menuliskan nama yang dipilih dalam secarik kertas atau dengan memberikan suaranya dalam pemilihan. ${ }^{1}$ Pemilu dianggap hal yang penting karena merupakan bentuk paling riil dari demokrasi serta wujud paling konkret keikutsertaan(partisipasi) rakyat dalam penyelenggaraan negara. Oleh sebab itu, sistem \& penyelenggaraan pemilu hampir selalu menjadi pusat perhatian utama karena melalui penataan, sistem \& kualitas penyelenggaraan pemilu diharapkan dapat benar-benar mewujudkan pemerintahan yang demokratis yang tentunya sesuai dengan harapan bersama. Pemilu sangatlah penting bagi sebuah negara, dikarenakan:

1. Pemilu merupakan sarana perwujudan kedaulatan rakyat

2. Pemilu merupakan sarana bagi pemimpin politik untuk memperoleh legitimasi 
3. Pemilu merupakan sarana bagi rakyat untuk berpartisipasi dalam proses politik.

4. Pemilu merupakan sarana untuk melakukan penggantian pemimpin secara konstitusional. Dalam hal ini yang berhak memilih adalah warga negara Indonesia yang telah genap berusia 17 tahun atau lebih atau sudah/pernah kawin. Seorang warga negara Indonesia yang telah mempunyai hak memilih, baru bisa menggunakan haknya, apabila telah terdaftar sebagai pemilih. $^{2}$ Pemilih pemula merupakan pemilih yang baru pertama kali memilih karena usia mereka baru memasuki usia pemilih yaitu 17 hingga 21 tahun. Pengetahuan mereka terhadap pemilu tidak berbeda jauh dengan kelompok lainnya, yang membedakan adalah soal antusiasme dan preferensi. Preferensi politik dapat disimpulkan sebagai sisi seseorang dimana dia memiliki kecenderungan dan kesukaan terhadap suatu pelaksanaan aktivitas politik baik itu berupa pemilu, pengambilan keputusan, berperan aktif dalam pemerintahan dan sebagainya.

\footnotetext{
2 Prof. H. Rozali Abdullah, S.H. Mewujudkan Pemilu yang Lebih Berkualitas (Pemilu Legislatif), PT. Raja Grafindo Persada, Jakarta, 2009, h. 168.

3 Ibid
}

Pemilih dalam setiap pemilihan umum didaftarkan melalui pendataan yang dilakukan oleh petugas yang ditunjuk oleh penyelenggara pemilihan umum. Adapun syarat-syarat yang harus dimiliki untuk menjadikan seseorang dapat memilih adalah: ${ }^{3}$

1. WNI yang berusia 17 tahun atau lebih atau sudah/pernah kawin.

2. Tidak sedang terganggu jiwa/ingatannya

3. Terdaftar sebagai pemilih.

4. Bukan anggota TNI/Polri (Purnawirawan / Sudah tidak lagi menjadi anggota TNI / Kepolisian).

5. Tidak sedang dicabut hak pilihnya

6. Terdaftar di DPT.

7. Khusus untuk Pemilukada calon pemilih harus berdomisili sekurang-kurangnya enam bulan didaerah yang bersangkutan. ${ }^{4}$

Pemilih pemula sangat memiliki andil yang besar dalam pemilu. Mereka sangat berperan sebagai pengawas partisipatif pada pemilu yang akan diselenggarakan. Partisipatif/ partisipasi adalah penentuan sikap dan keterlibatan

4 Yusdianto, Identifikasi Potensi Pelanggaran Pemilihan Kepala Daerah (Pemilukada) dan Mekanisme PenyelesaiiannyaI. Jurnal Konstitusi Vol II nomor 2, November 2010, h. 44. 
hasrat setiap individu dalam situasi dan kondisi organisasinya, sehingga pada akhirnya mendorong individu tersebut berperan serta dalam pencapaian tujuan organisasi, serta ambil bagian dalam setiap pertanggungjawaban bersama. $^{5}$ Istilah partisipasi politik diterapkan kepada aktivitas orang dari semua tingkat sistem politik; pemilih (pemberi suara) berpartisipasi dengan memberikan suaranya; menteri luar negeri berpartisipasi dalam menetapkan kebijaksanaan luar negeri. Kadang-kadang istilah tersebut lebih diterapkan pada orientasi politik daripada aktivitas politik; warga Negara berpartisipasi dengan menaruh minat dalam politik. ${ }^{6}$ John Stuart Mill dalam Miriam Budiardjo (1994) menyatakan bahwa partisipasi dalam kehidupan politik dapat menyebabkan pengembangan kapasitas pribadi "tertinggi dan serasi" dalam rangka menuju jalan kebebasan dan pengembangan diri. Di negara-negara demokratis, pemikiran yang mendasari konsep partisipasi politik ialah bahwa kedaulatan ada di tangan rakyat yang

5 Arifin Rahman, Sistem Politik Indonesia Dalam Perspektif Struktural Fungsional, SIC, Surabaya, 2002, h. 128.

${ }^{6}$ Ibid, h. 129.

7 Prof. Miriam Budiardjo, Demokrasi Di Indonesia Demokrasi Parlementer dan Demokrasi Pancasila, PT. Gramedia Pustaka Utama, 1994, Jakarta, h. 184. melaksanakannya melalui kegiatan bersama untuk menetapkan tujuan-tujuan serta masa depan masyarakat itu dan untuk menentukan orang-orang yang akan memegang tampuk pimpinan. ${ }^{7}$ Herbert McClosky seorang tokoh masalah partisipasi berpendapat: "partisipasi politik adalah kegiatan-kegiatan sukarela dari warga masyarakat melalui mana mereka mengambil bagian dalam proses pemilihan penguasa, dan secara langsung atau tidak langsung dalam proses pembentukan kebijakan umum" (the term "political participation" will refer to those voluntary activities by which members of a society share in the selection of rulers and, directly or indirectly, in the formation of public policy"). ${ }^{8}$

Partisipasi politik yang meluas merupakan ciri khas modernisasi politik. Di dalam masyarakat tradisional, pemerintahan dan politik biasanya hanya merupakan urusan satu golongan elit yang kecil. ${ }^{9}$ Sebagai definisi umum dapat dikatakan bahwa partisipasi politik adalah kegiatan seseorang atau kelompok orang untuk ikut serta secara aktif dalam

8

9 Samuel P. Huntington dan John Nelson, Partisipasi Politik di Negara Berkembang, Rineka Cipta, Jakarta, 1994, h. 1. 
kehidupan politik, antara lain dengan jalan memilih pemimpin Negara dan, secara langsung atau tidak langsung, memengaruhi kebijakan pemerintah (public policy). Kegiatan ini mencakup tindakan seperti memberikan suara dalam pemilihan umum, mengadakan hubungan (contacting) atau lobbying dengan pejabat pemerintah atau anggota parlemen, menjadi anggota partai atau salah satu gerakan sosial dengan direct actionnya, dan sebagainya. ${ }^{10}$

Dalam hal ini, partisipasi politik oleh pemilih pemula sangatlah penting karena sebanyak $20 \quad \%$ dari seluruh pemilih adalah pemilih pemula, dengan demikian jumlah pemilih pemula sangatlah besar, sehingga hak warga negara dalam menggunakan hak pilihnya janganlah sampai tidak berarti akibat dari kesalahan-kesalahan yang tidak diharapkan, misalnya jangan sampai sudah memiliki hak pilih tidak dapat menggunakan hak pilihnya karena tidak terdaftar atau juga masih banyak kesalahan dalam menggunakan hak pilihnya, dll. Siapapun itu yang bisa merebut perhatian kalangan akan dapat merasakan keuntungannya. Lahirnya

10 Prof. Miriam Budiardjo, Dasar-dasar Ilmu Politik, PT Gramedia Pustaka Utama, Jakarta, 2008, h. 367 dukungan dari kelompok ini secara tidak langsung membawa dampak pencitraan yang sangat berarti. Setidaknya untuk pengamanan proses regenerasi kader politik kedepan, meskipun membutuhkan biaya yang tidak sedikit. Ketiadaan dukungan dari kalangan ini akan terasa cukup merugikan bagi target-target suara pemilu yang telah ditetapkan tiap-tiap parpol.

Pemilih pemula yang terdiri atas pelajar, mahasiswa atau pemilih dengan rentang usia 17-21 tahun menjadi segmen yang memang unik, sering kali memunculkan kejutan dan tentu menjanjikan secara kuantitas. Disebut unik,sebab perilaku pemilih pemula dengan antusiasme tinggi, relatif lebih rasional, haus akan perubahan dan tipis akan kadar polusi pragmatisme. Pemilih pemula memiliki antusiasme yang tinggi sementara keputusan pilihan yang belum bulat, sebenarnya menempatkan pemilih pemula sebagai swing vooters yang sesungguhnya. Pilihan politik mereka belum dipengaruhi motivasi ideologis tertentu dan lebih didorong oleh konteks dinamika lingkungan politik lokal. Pemilih pemula mudah dipengaruhi 
kepentingan-kepentingan tertentu, terutama oleh orang terdekat seperti anggota keluarga, mulai dari orang tua hingga kerabat dan teman. Selain itu, media massa juga lkut berpengaruh terhadap pilihan pemilih pemula. Hal ini dapat berupa berita ditelevisi, spanduk, brosur, poster, dan lain-lain. Pemilih pemula khususnya remaja (berusia 17 tahun) mempunyai nilai kebudayaan yang santai, bebas, dan cenderung pada hal-hal yang informal dan mencari kesenangan, oleh karena itu semua hal yang kurang menyenangkan akan dihindari. Disamping mencari kesenangan, kelompok sebaya adalah paling penting dalam kehidupan seorang remaja, sehingga bagi seorang remaja perlu mempunyai kelompok teman sendiri dalam pergaulan. ${ }^{11}$

Dalam penghitungan suara pemilu, satu suara saja sangat berarti karena bisa mempengaruhi kemenangan politik. Apalagi suara yang berjumlah jutaan sebagaimana halnya yang dimiliki kalangan Pemilih pemula. Itu sebabnya, dalam setiap pemilu pemilih pemula menjadi "rebutan" berbagai kekuatan politik. Menjelang pemilu, partai politik atau peserta pemilu lainnya, biasanya

\footnotetext{
${ }^{11}{ }_{\text {http://digilib.sunanampel. }}$ ac.id/files/disk1/191/jiptiain--miraatunni-9509-5-bab2.pdf, diakses pada tanggal 14 Oktober 2019, pukul 16.20 WIB.
}

membuat iklan atau propaganda politik yang menarik para pemilih pemula. Mereka juga membentuk komunitas kalangan muda dengan aneka kegiatan yang menarik anak-anak muda, khususnya pemilih pemula. Tujuannya agar para pemilih pemula tertarik dengan partai atau kandidat tersebut dan memberikan suaranya dalam pemilu untuk mereka sehingga mereka dapat mendulang suara yang signifikan dan meraih kemenangan. Oleh karena itu, partisipasi politik pemilih pemula sangat memililki andil yang besar dalam pemilihan umum (pemilu) ${ }^{12}$

\section{METODE}

Metode penelitian yang digunakan metode deskriptif analisis, yaitu suatu metode penelitian untuk memperoleh gambaran mengenai situasi dan keadaan dengan cara pemaparan data yang diperoleh sebagaimana adanya, yang kemudian melalui berbagai analisis disusun beberapa kesimpulan. Metode pendekatan yang digunakan adalah yuridis normatif karena menggunakan data sekunder sebagai sumber utama. Adapun data yang

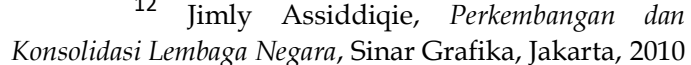
h. 5
} 
digunakan dalam menyusun tulisan ini diperoleh dari penelitian kepustakaan (library research). Peneliti menggunakan pendekatan metode empiris (Yuridis Sosiologis) dalam penelitian dimana metode penelitan ini banyak digunakan pada penelitian yang bertujuan untuk menjelaskan suatu kejadian.

\section{HASIL DAN PEMBAHASAN}

Dari definisi yang diungkapkan di atas, bahwa pemilih pemula adalah pemilih yang baru pertama kali memilih karena usia mereka baru memasuki usia pemilih yaitu 17 hingga 21 tahun. Secara psikologis, Pemilih pemula memiliki karakteristik yang berbeda dengan orangorang tua pada umumnya. Pemilih pemula cenderung kritis, mandiri, independen, anti status quo atau tidak puas dengan kemapanan, pro perubahan dan sebagainya. Karakteristrik itu cukup kondusif untuk membangun komunitas pemilih cerdas dalam pemilu yakni pemilih yang memiliki pertimbangan rasional dalam menentukan pilihannya. Misalnya karena integritas tokoh yang dicalonkan partai politik, track record atau program kerja yang ditawarkan. Karena

\footnotetext{
${ }^{13}$ http://www.antara.net.id/index.php/2014/01/0 2/pemilih-pemula- pemilu-2014-potensi-besar-sosialisasi-
}

belum punya pengalaman memilih dalam pemilu, pemilih pemula perlu mengetahui dan memahami berbagai hal yang terkait dengan pemilu. Misalnya untuk apa pemilu diselenggarakan, apa saja tahapan pemilu, siapa saja yang boleh ikut serta dalam pemilu, bagaimana tata cara menggunakan hak pilih dalam pemilu dan sebagainya. Pertanyaan itu penting diajukan agar Pemilih Pemula menjadi pemilih cerdas dalam menentukan pilihan politiknya di setiap pemilu. ${ }^{13}$

Pemilih pemula yang berperan penting menentukan arah perubahan kemajuan Indonesia memiliki potensi akan berhasil memenangkan Pemilu yang akan berlangsung. Dengan jumlah perkiraan pemilih pemula yang besar maka jelas akan berpotensi memenangkan Pemilu, sehingga sayang rasanya jika suara dari pemilih pemula ini diabaikan oleh pihak-pihak yang berkepentingan dalam Pemilu dan sepatutnya harus mampu untuk dirangkul agar pemilih pemula aktif dalam partisipasi politik yang dalam hal ini berpartisipasi memilih dan tidak golput mengingat ini merupakan suatu peluang untuk mencapai kemenangan dalam pemilu ketika suara pada pukul 19.00 WIB 
pemilih pemula dapat dirangkul oleh otoritas politik.

Secara umum menurut riset International IDEA (2016), "Voters Turnout Trends around the World", tren partisipasi pemilih dalam pemilu secara global mengalami penurunan signifikan sejak 1990-an. Jumlah pemilih global cukup stabil antara tahun 1940-an. Era 1980-an, menurun dari 78 persen menjadi 76 persen. Pada 1990-an turun sampai 70 persen, dan terus mengalami penurunan mencapai 66 persen periode 2011-2015. Untuk Asia dan Amerika, tren jumlah pemilih relatif stabil dari waktu ke waktu, namun di kedua wilayah jumlah pemilih telah jauh di bawah rata-rata global. ${ }^{14}$ Selain itu berdasarkan Hasil survei organisasi partisipasi pemilu, Jeune \& Raccord (J\&R) menyebut potensi golput atau tidak memilih di kalangan milenial pada pemilu presiden 2019 mencapai lebih dari 40 persen. Survei itu melibatkan 1.200 responden di seluruh provinsi Indonesia pada 10-16 Maret 2019 dengan margin of error kurang lebih 2,8 persen. Tingginya angka golput tersebut

$14 \quad$ http://ksp.go.id/partisipasi-pemilih-dalampemilu/, diakses 14 Oktober 2019 pada pukul 19.30 WIB disebabkan oleh ketidakpedulian generasi milenial terhadap politik dan kurangnya informasi waktu pencoblosan pilpres, dengan persentase masingmasing 65,4 persen dan 25,3 persen. Jumlah daftar pemilih tetap (DPT) pemilu serentak 2019 yang telah ditetapkan KPU sebanyak lebih dari 192 juta orang. Dari jumlah tersebut, 100 juta di antaranya berumur 17 tahun hingga 39 tahun atau yang kerap disebut sebagai generasi milenial atau pemilih pemula. ${ }^{15}$

Dewasa ini, banyak terdapat sejumlah kendala yang terkait dengan pemilih pemula yang di antaranya pertama, pemilih pemula yang pada 17 April 2019 berumur 17 tahun dan ingin mengikuti Pemilu masih banyak yang belum melakukan perekaman dan pencetakan e-KTP, alias belum memiliki e-KTP. Kedua, syarat perekaman, penerbitan, dan pemberian e-KTP baru bisa dilakukan pas di hari ketika penduduk berusia 17 tahun. Sementara bila dilakukan perekaman dan penerbitan e-KTP tepat di hari pemungutan suara pada 17 April 2019 meskipun dijanjikan Mendagri Tjahjo

${ }^{15}$ https://www.voaindonesia.com/a/potensigolput-milenial-capai-40-persen, diakses 14 Oktober 2019 pada pukul 20.00 WIB 
Kumolo bisa dilakukan hanya dalam waktu satu jam jika seluruh persyaratan terpenuhi bisa dianggap melanggar aturan dan sangat riskan dilakukan. Apalagi di hari libur karena dipastikan seluruh rakyat Indonesia yang memenuhi syarat pemilih tengah berkonsentrasi untuk mengikuti Pemilu 2019. Ketiga, dalam UU No. 7 tahun 2017 tentang Pemilu diatur mengenai Daftar Pemilih Tambahan (DPTb) atau pemilih yang telah terdaftar dalam DPT di suatu TPS yang karena keadaan tertentu Pemilih tidak dapat menggunakan haknya untuk memilih di TPS tempat yang bersangkutan terdaftar dan memberikan suara di TPS lain. Syaratnya, harus menunjukkan e-KTP atau Surat Keterangan (Suket) dan salinan bukti telah terdaftar sebagai Pemilih dalam DPT di TPS asal dengan menggunakan formulir Model A.A.1KPU (PKPU No. 11 tahun 2018, Pasal 37 ayat 1). Selain itu, pada Pasal 348 UU No. 7 tahun 2017 tentang Pemilu mengatur bahwa pada Pemilu 2019, untuk pertama kalinya, kepemilikan KTP elektronik (KTP-E) menjadi syarat sah bagi warga negara untuk dapat menggunakan hak pilih. Tanpa KTP-E, mereka tak bisa memilih. Jadi, meskipun pemilih pemula sudah masuk dalam DPT, jika tidak mempunyai e-KTP atau Suket, tidak dapat menyalurkan hak pilihnya.

Disamping itu terdapat pula masalah lainnya di antaranya pertama, pemilih pemula rawan dipolitisasi dan dijadikan komoditas politik untuk mendongkrak popularitas dan elektabilitas kontestan Pemilu, baik Pilpres maupun Pileg. Kedua, pemilih pemula rawan didekati, dipersuasi, dipengaruhi, dimobilisasi, dan sebagainya untuk bersedia mengikuti kampanye yang dilaksanakan. Padalah sebelum ini, para kontestan Pemilu tersebut tidak jelas kepeduliannya terhadap pemilih pemula. Ketiga, pemilih pemula masih banyak mengidap penyakit labilitas dan emosionalitas. Dalam kontek Pemilu, mereka berada dalam pusaran antara antusiasme politik dengan apatisme politik. Pada satu sisi sangat bersemangat dan ingin mengetahui seputar Pemilu, khususnya melalui media sosial. Namun, belum tentu antusiasisme tersebut simetris dengan realitas perilaku politiknya. Bahkan tidak sedikit kalangan pemilih 
pemula, termasuk mahasiswa, lebih memilih tidak menyalurkan hak pilihnya alias Golput. Dengan kata lain antusiasisme politik kalangan muda, khususnya pemilih pemula di politik lebih merefleksikan suatu fenomena romantisme politik atau sensate democracy. Keempat, pemilih pemula sering menjadi sasaran empuk politik transaksional, atau politik uang. Politik uang dalam konteks pemilih pemula bisa berangkat atas inisiatif dari partai politik, tim kampanye, dan para calo politik (political broker). Tetapi, bisa juga berasal dari inisiatif pemilih pemula itu sendiri. Jangan lupa, di antara pemilih pemula juga sudah mengenal politik uang serta sumber-sumber dari politik uang tersebut. Hanya saja politik uang di kalangan pemilih pemula cenderung hanya dalam jumlah terbatas, recehan atau eceran. Bukan dalam jumlah besar, glosiran, partaian, atau kardusan. Kelima, pemilih pemula belum berpengalaman dalam mengikuti kegiatan Pemilu, khususnya pemberian suara di Tempat Pemungutan Suara (TPS). Kegiatan ini gampang-gambang susah. Terlebih pada Pemilu Serentak 2019 di mana surat suara (ballot paper) yang harus 'dicoblos' oleh pemilih cukup banyak, yakni: (1) untuk Capres dan Cawapres, (2) anggota DPR, (3) anggota DPD, (4) anggota DPRD Provinsi dan (5) untuk anggota DPRD Kabupaten/Kota (di Jakarta tidak ada DPRD Kabupaten/Kota). Bukan tidak mungkin, pemilih pemula tidak mengetahui sah dan tidak sahnya pencoblosan surat suara.

Selain masalah diatas, terdapat juga faktor- faktor yang mempengaruhi keikutsertaan pemilih pemula dalam menentukan pilihan politiknya. Contohnya karakteristik sosial dan pengelompokan sosial yang mempunyai pengaruh-pengaruh yang cukup signifikan dalam menentukan perilaku pemilih seseorang. Karakteristik sosial seperti pekerjaan, pendidikan sampai karakteristik sosiologis seperti agama, wilayah, jenis kelamin, umur dan sebagainya merupakan bagian-bagian dan faktor-faktor penting dalam menentukan pilihan politik. Singkat kata, pengelompokan sosial seperti umur, jenis kelamin, agama dan semacamnya dianggap mempunyai peranan yang cukup menentukan dalam membentuk pengelompokan seseorang. Hal ini merupakan sesuatu yang sangat vital 
dalam memahami perilaku politik seseorang. Selain itu, faktor pendekatan psikologis juga memiliki pengaruh terhadap pilahan politik seseorang. Pilihan seseorang anak yang telah melalui tahap sosialisasi politik tidak jarang sama dengan pilihan politik orang tuanya. Pendekatan psikologis menekankan pada tiga aspek psikologis sebagai kajian utama yaitu ikatan emosional pada suatu partai politik, orientasi terhadap isu-isu dan orientasi kepada kandidat. Selain pendekatan psikologis, terdapat pendekatan rasional. Pemilih pemula akan memilih jika ia merasa ada timbal balik yang akan diterimanya. Ketika pemilih merasa tidak mendapatkan faedah dengan memilih calon legislatif yang sedang bertanding, ia tidak akan mengikuti dan melakukan pilihan pada proses Pemilu. Hal ini juga sejalan dengan prinsip ekonomi dan hitung ekonomi. Pendekatan ini juga mengandaikan bahwa calon legislatif akan melakukan berbagai promosi dan kampanye yang bertujuan untuk menarik simpati dan keinginian masyarakat untuk memilih dirinya pada pemilu. ${ }^{16}$

16 Samuel Huntington, Partisipasi Politik di Negara Berkembang, Rineka Cipta, Jakarta, 1994, h. 13
Survei J\&R juga mengungkapkan generasi milenial yang mengikuti isu politik lebih banyak di perkotaan dibandingkan dengan desa dengan perbandingan 40,35 persen dan 27,5 persen. Dari sisi gender, milenial laki-laki juga lebih banyak mengikuti isu politik dibandingkan perempuan dengan persentase 35 persen berbanding 29 persen. Sementara dari sisi pendidikan, milenial yang berpendidikan tinggi juga lebih banyak mengikuti isu politik ketimbang milenial berpendidikan rendah yakni 42,7 persen dan 29,8 persen. ${ }^{17}$

Di era modern ini dunia mengalami kegoncangan nilai dan norma yang cukup kuat. Krisis moral dan etika kehidupan berbangsa terutama krisis nilai pada aspek politik begitu terasa, contohnya saja peningkatan angka golput pada setiap penyelenggaraan pemilu. Selain itu, penyimpangan etika privat dan etika publik dalam bernegara mengalami peningkatan dan kekacauan norma seakan-akan terus terjadi dalam praktik pengelolaan negara sehingga dalam suasana globalisasi kita gamang

${ }^{17}$ https://www.voaindonesia.com/a/potensigolput-milenial-capai-40-persen, diakses 14 Oktober 2019 pada pukul $20.00 \mathrm{WIB}$ 
menghadapinya, dengan sikap responsif. ${ }^{18}$

Tindakan politik yang senantiasa mendasarkan diri pada etika tentu akan selalu menghasilkan kebaikan-kebaikan bersama yang lebih besar dari pada sekedar tindakan politik yang hanya mementingkan kepentingan sesaat. Karena etika pada hakikatnya memiliki landasan pemikiran kritis berkaitan dengan ajaran-ajaran maupun pandanganpandangan tentang moral dalam konteks kehidupan sebagai umat manusia yang memiliki potensi kebaikan. Memilih untuk golput sama saja dengan mengabaikan nilai-nilai etika dalam bernegara. ${ }^{19}$ Oleh karena itu diharapkan kepada generasi milenial dan pemilih pemula untuk menerapkan nilai-nilai etika dengan ikut berperan aktif dan tidak golput dalam pesta demokrasi. ${ }^{20}$ Mereka jadi segmen yang sangat strategis untuk dilibatkan partisipasinya dalam memberikan kontribusi bagi Indonesia. Membangun persepsi bahwa politik yang baik dan sehat itu adalah hal penting menjadi mendesak dilakukan. Jangan sampai para pemilih pemula ini terus terjebak pada apatisme politik yang membuat

18 Jimly Asshiddiqie, Menegakkan Etika Penyelenggara Pemilu, Raja grafindo, Jakarta, 2013, h. 22, dan 29-30

${ }^{19}$ Ibid. mereka kehilangan selera untuk terlibat aktif dalam partisipasi politik. ${ }^{21}$

\section{KESIMPULAN}

UU No. 7 tahun 2017 tentang Pemilu memberikan jaminan bagi pemilih pemula yang pada saat pemilu berlangsung genap berusia 17 tahun guna menyalurkan hak pilihnya pada pesta demokrasi. Secara kuantitatif, jumlah pemilih pemula cukup besar dan berkontribusi signifikan bagi kemenangan Pasangan Calon Calon Presiden dan Wakil Presiden pada Pemilu Presiden dan Wakil Presiden (Pilpres) maupun Pemilihan Anggota DPR, DPD dan DPRD atau Pemilu Legislatif (Pileg). Namun demikian, dalam aktualisasi hak pilih mereka masih mengandung masalah dan bahkan potensial yang menyebabkan pemilih pemula kehilangan hak pilihnya. Masalah ini tidak boleh dibiarkan berlarut-larut dan dicarikan solusinya untuk menyelamatkan jutaan hak pilih kelompok potensial ini pada Pemilu yang akan berlangsung. Selain masih

\footnotetext{
20 Jimly Asshidiqie, Peradilan Etik Dan Etika Konstitusi, Sinar Grafika, Jakata Timur , 2014 h. 278-281

${ }^{21}$ https://www.kompasiana.com/mahfudm d_info, diakses 17 Oktober 2019 pada pukul 13.35 WIB
} 
banyaknya kendala terkait dengan administrasi, perlu juga dilakukan gerakan nasional untuk mengurangi potensi golput di kalangan milenial dan pemilih pemula. Gerakan tersebut dapat berupa sosialisasi kepada pemilih pemula agar mengambil andil dalam pesta demokrasi ini. Menyampaikan segala informasi pemilu termasuk hari $\mathrm{H}$, kapan pencoblosan, bagaimana cara nya, dimana tempatnya, serta segala hal yang terkait dengan penyelenggaraan pemilu. Gerakan ini dilakukan agar demokrasi di Indonesia dapat menjadi sehat, yang salah satu syaratnya yaitu partisipasi aktif dari warga Negara termasuk para pemilih pemula. 


\section{DAFTAR PUSTAKA}

\section{A. BUKU}

Abdullah, Rozali, 2009, Mewujudkan Pemilu yang Lebih Berkualitas (Pemilu Legislatif), PT. Raja Grafindo Persada, Jakarta.

Al-Iman, Abu Nashr Muhammad, 2004, Membongkar Dosa-dosa Pemilu, Prisma Media, Jakarta.

Asshidiqie, Jimly, 2014, Peradilan Etik Dan Etika Konstitusi, Sinar Grafika, Jakata Timur. Asshiddiqie, Jimly, 2013, Menegakkan Etika Penyelenggara Pemilu, Raja grafindo, Jakarta Assiddiqie, Jimly, 2010, Perkembangan dan Konsolidasi Lembaga Negara, Sinar Grafika, Jakarta.

Budiardjo, Miriam, 2008, Dasar-dasar Ilmu Politik, PT Gramedia Pustaka Utama, Jakarta.

Budiardjo, Miriam, 1994, Demokrasi Di Indonesia Demokrasi Parlementer dan Demokrasi Pancasila, PT. Gramedia Pustaka Utama, Jakarta.

Huntington, Samuel, 1994, Partisipasi Politik di Negara Berkembang, Rineka Cipta, Jakarta. Nelson, John dan Samuel P. Huntington, 1994, Partisipasi Politik di Negara Berkembang, Rineka Cipta, Jakarta.

Rahman, Arifin, 2002, Sistem Politik Indonesia Dalam Perspektif Struktural Fungsional, SIC, Surabaya.

Yusdianto, November 2010, Identifikasi Potensi Pelanggaran Pemilihan Kepala Daerah (Pemilukada) dan Mekanisme PenyelesaiiannyaI, Jurnal Konstitusi Vol II nomor 2, Jakarta. 


\section{B. ARTIKEL}

Eko Sulistyo, Partisipasi Pemilih dalam Pemilu, 05 Maret 2019, diperoleh dari http://ksp.go.id/partisipasi-pemilih-dalam-pemilu/, diakses 14 Oktober 2019 pada pukul 19.30 WIB

Mahfud, MD, Pentingnya Para Pemilih Pemula dalam Pemilu, 24 Juni 2015, diperoleh dari https://www.kompasiana.com/mahfudmd_info/diakses 17 Oktober 2019 pada pukul 13.35 WIB

Miko Elfisha, Pemilih Pemula dan Muda Tentukan Arah Bangsa, 16 April 2019 diperoleh dari http://www.antara.net.id/index.php/2014/01/02/pemilih-pemula-pemilu-2014-potensibesar-sosialisasi-program-yang-belum-merata/id/, diakses 14 Oktober 2019 pada pukul 19.00 WIB

Sasmito Madrim, Potensi Golput Milenial Capai 40 Persen , 4 April 2019 diperoleh dari https://www.voaindonesia.com/a/potensi-golput-milenial-capai-40-persen, diakses 14 Oktober 2019 pada pukul 20.00 WIB

http://digilib.sunanampel.ac.id/files/disk1/191/jiptiain--miraatunni-9509-5-bab2.pdf,diakses pada tanggal 14 Oktober 2019, pukul 16.20 WIB. 